\title{
Analysis of the Effect of Work Environment, Organizations, and Individual Factors on Job Satisfaction
}

\author{
Sri Rahayu*, Roselina Panghiyangani" ${ }^{* *}$, Lenie Marlinae ${ }^{* * * *}$, Husaini*, Eko Suhartono ${ }^{* * * * *}$ \\ * Master of Public Health, Faculty of Medicine, Lambung Mangkurat University, Indonesia \\ ** Department of Biomedicine, Faculty of Medicine, Lambung Mangkurat University, Indonesia \\ **** Public Health Study Program, Faculty of Medicine, Lambung Mangkurat University, Indonesia \\ ***** Department of Biochemistry, Faculty of Medicine, Lambung Mangkurat University, Indonesia
}

DOI: 10.29322/IJSRP.10.06.2020.p10271

http://dx.doi.org/10.29322/IJSRP.10.06.2020.p10271

\begin{abstract}
Nurses have become a critical role in the process of providing treatment in hospitals because of their involvement with the patient for 24 hours. Therefore, nurses become a determining factor in quality and hospital image; nurses are required to provide professional services. It can be seen by the performance they provide to increase the service of human resurrection, including them so that they have to consider the factors of satisfaction in work. The level of employee satisfaction in Suaka Insan Hospital is less than the standard that has been set before $(\geq 80 \%)$ that is (2017) and 69\% (2016). This research aims to analyze environmental, organizational and individual factors on job satisfaction in the Inpatient Installation at Suaka Insan Hospital Banjarmasin. This is a quantitative research using cross-sectional. Sampling with purposive sampling with a total sample of 51 people. Data collection using a questionnaire. Data analysis uses SmartPLS version 3.0. Nurses at the Inpatient Installation of Suaka Insan Hospital Banjarmasin stated that Suaka Insan Hospital Banjarmasin has a high work environment factor (100\%), a low organizational factor $(59 \%)$ and a low individual factor (80\%). SmartPLS statistical test version 3.0 shows that there is an influence of environmental factors on job satisfaction $(3,297)$, there is an influence of organizational factors on job satisfaction $(4,632)$, there is no individual effect factor on job satisfaction $(0,431)$, and together work environment, organizational and individual factors influence job satisfaction (38.5). Work environment and organizational factors are proven to affect job satisfaction. While individual factors have not been proven to affect job satisfaction. However, work environment, organization and individual factors together affect job satisfaction.
\end{abstract}

Index Terms- work environment, organization, individual, job satisfaction

\section{INTRODUCTION}

$\mathrm{T}$ The hospital provides health services which include inpatient, outpatient and emergency services. As a service provider, a hospital requires a variety of resources, one of which is human resources which play an essential role in an organization because human resources that perform management functions within a company or organization include planning, implementing and controlling in achieving the objectives of the company or organization (Law of Republic of Indonesia, 2009; Kamal, 2018; Rachman, 2016; Mahriani, 2014).

Nurses at the hospital become the deciding factor and image quality of hospital services. Therefore, nurses required in order to provide professional services in running kan duties by growing care and empathy towards patients. Professional health services can be seen from the performance provided where performance appraisals of all nurses are usually conducted annually (Halim, 2018; Arini, 2018; Rachman, 2016; Dala, 2015; Sitepu, 2014).

Performance can be interpreted as the level of success of a person in carrying out the task and his ability to achieve the goals set and improve the performance of human resources, including nurses. It is necessary to consider factors of satisfaction in work. Job satisfaction is determined by several aspects including aspects of work, salary, company management, supervision, intrinsic factors of work, working conditions, social aspects of work, communication and colleagues (Halim, 2018; Arini, 2018; Rachman, 2016; Dala, 2015; Sitepu, 2014).

According to Best and Trusthon in Putri (2016), job satisfaction is determined by three main factors, namely environmental, organizational and individual factors. Work environment factors that can determine job satisfaction include workload, work time, workplace security, relationships between work units, between employees, with superiors, completeness of work tools, and workplace atmosphere. Organizational factors that can determine job satisfaction include salary, payroll structure, incentives, employee benefits, health insurance, pension guarantees, management policies, involvement in the organization, training, rewards for achievement and career development. Meanwhile, individual employee factors include age, education, years of service, gender, and marital status (Putri, 2016).

According to the results of research conducted by Subramaniam in Renea (2018) and Adhi research (2018), job satisfaction in the private sector is higher than employees in the public sector. However, the job satisfaction rate at Suaka Insan Hospital is less than the specified standard. Suaka Insan Hospital Banjarmasin is one of the private hospital type $\mathrm{C}$ in Banjarmasin 
that provides inpatient, outpatient and emergency medical services (Renea, 2018; Adhi, 2018).

Based on data from the Suaka Insan Hospital Banjarmasin 2018 in the report Friani (2018) note that $76 \%$ of employees are satisfied with environmental factors in the Suaka Insan Hospital Banjarmasin covering workplace safety, workplace atmosphere, appropriate equipment, labour and quality of relationships between individual among peers work together. Employee satisfaction with organizational factors of $68 \%$ which includes wages, job guarantees, company policies, involvement in the organization, training, rewards for restoration and career development.

\section{RESEARCH METHOD}

This research is quantitative research with crosssectional analytic research design. The population in this study were all female nurses in Inpatient Suaka Insan Hospital Banjarmasin with a total of 85 people. The sample is nurses in Banjarmasin Inpatient Suaka Insan Hospital Banjarmasin with inclusion criteria amounting to 51 people. The data analysis technique used in this study is Structural Equation Modeling (SEM).

\section{FINDINGS}

Table 1. Distribution and Frequency of Work Environment, Organizational, Individual Factors and Job Satisfaction at Suaka Insan Banjarmasin Hospital

\begin{tabular}{|c|c|c|c|c|c|c|}
\hline \multirow{3}{*}{ Indicator } & \multicolumn{4}{|c|}{ Category } & \multicolumn{2}{|c|}{ Total } \\
\hline & \multicolumn{2}{|c|}{ High } & \multicolumn{2}{|c|}{ Low } & \multirow[b]{2}{*}{$\mathbf{F}$} & \multirow[b]{2}{*}{$\%$} \\
\hline & $\mathbf{F}$ & $\%$ & $\mathbf{F}$ & $\%$ & & \\
\hline \multicolumn{7}{|l|}{ Work Environment } \\
\hline Security & 51 & 100 & 0 & 0 & 51 & 100 \\
\hline Atmosphere & 51 & 100 & 0 & 0 & 51 & 100 \\
\hline Equipment completeness & 43 & 84 & 8 & 16 & 51 & 100 \\
\hline Relationship quality & 51 & 100 & 0 & 0 & 51 & 100 \\
\hline \multicolumn{7}{|l|}{ Organizational Factors } \\
\hline Wages & 7 & 14 & 44 & 86 & 51 & 100 \\
\hline Job security & 32 & 63 & 19 & 37 & 51 & 100 \\
\hline Company policy & 34 & 67 & 17 & 33 & 51 & 100 \\
\hline $\begin{array}{l}\text { Involvement in } \\
\text { organizations }\end{array}$ & 49 & 96 & 2 & 4 & 51 & 100 \\
\hline Training & 44 & 86 & 7 & 14 & 51 & 100 \\
\hline Award for achievement & 28 & 55 & 23 & 45 & 51 & 100 \\
\hline Career development & 34 & 67 & 17 & 33 & 51 & 100 \\
\hline \multicolumn{7}{|l|}{ Individual Factors } \\
\hline \multicolumn{7}{|l|}{ Age } \\
\hline $17-25$ & - & - & - & - & 4 & 8 \\
\hline $26-35$ & - & - & - & - & 34 & 67 \\
\hline $36-45$ & - & - & - & - & 11 & 21 \\
\hline $46-55$ & - & - & - & - & 2 & 4 \\
\hline \multicolumn{7}{|l|}{ Years of service } \\
\hline$<5$ years & - & - & - & - & 5 & 10 \\
\hline 5 - 9 years & - & - & - & - & 21 & 41 \\
\hline 10-14 years & - & - & - & - & 17 & 33 \\
\hline 15 years & - & - & - & - & 8 & 16 \\
\hline
\end{tabular}

\begin{tabular}{lcccccc} 
Diploma III Nursing & - & - & - & - & 44 & 86 \\
Bachelor of Nursing & - & - & - & - & 4 & 8 \\
Nurse & - & - & - & - & 3 & 6 \\
Master of Nursing & - & - & - & - & 0 & 0 \\
& & & & & & \\
Marital status & & & & & & \\
Single & - & - & - & - & 16 & 31 \\
Married & - & - & - & - & 30 & 59 \\
Widowed & - & - & - & - & 5 & 10 \\
\hline Job Satisfaction & & & & & & \\
Enjoy the work & 51 & 100 & 0 & 0 & 51 & 100 \\
Love the work & 45 & 88 & 6 & 12 & 51 & 100 \\
Work morale & 51 & 100 & 0 & 0 & 51 & 100 \\
Discipline & 49 & 96 & 2 & 4 & 51 & 100 \\
Work performance & 51 & 100 & 0 & 0 & 51 & 100 \\
\hline
\end{tabular}

Table 2. Effect of Work Environment, Organizational, Individual Factors Toward Job Satisfaction at Suaka Insan Banjarmasin Hospital

\begin{tabular}{|c|c|c|c|c|}
\hline \multirow{3}{*}{ Indicator } & \multicolumn{4}{|c|}{ Category Y } \\
\hline & \multicolumn{2}{|c|}{ High } & \multicolumn{2}{|c|}{ Low } \\
\hline & $\mathbf{F}$ & $\%$ & $\mathbf{F}$ & $\%$ \\
\hline $\begin{array}{l}\text { Category X1 (Work Environment } \\
\text { Factors) }\end{array}$ & 51 & 100 & 0 & 0 \\
\hline $\begin{array}{l}\text { Category X2 (Organizational } \\
\text { Factors) }\end{array}$ & 21 & 41 & 30 & 59 \\
\hline Category X3 (Individual Factors) & 10 & 20 & 41 & 80 \\
\hline \multicolumn{5}{|c|}{$\begin{array}{l}\text { Table 3. Hypothesis Test Results Based on the t-Value on Output } \\
\text { Output of SmartPLS and f Square Value }\end{array}$} \\
\hline & \multicolumn{2}{|c|}{ t-Value } & \multicolumn{2}{|c|}{ f Square } \\
\hline Work Environment Factors (X1) & \multicolumn{2}{|c|}{3.297} & \multicolumn{2}{|c|}{0.197} \\
\hline Organizational Factors (X2) & \multicolumn{2}{|c|}{4.632} & \multicolumn{2}{|c|}{0.444} \\
\hline Individual Factor (X3) & \multicolumn{2}{|c|}{0.431} & \multicolumn{2}{|c|}{0.006} \\
\hline
\end{tabular}

\section{DISCUSSION}

1. Effect of Environmental Factors on Job Satisfaction

In this study, all indicators of work environment factors which include safety, work environment, completeness of work tools and relationship quality are in the high category and if related to the percentage of job satisfaction also tend to be high including enjoying the work, loving the work, work morale, discipline and work performance. Judging from the t-value of statistics for each question on the work environment variable on the indicator of the work environment itself which will lead to job satisfaction, it can be seen that all the statistical $t$ values for each question exceed the value of t table (2.00958) as shown in the output results SmartPLS output. This causes the influence of work environment factors on job satisfaction.

The results of this study are consistent with research conducted by Anderson (2017) related to the Influence of Leadership and Non-Physical Work Environment on Nurse Job Satisfaction Through Nurse Turn Over Intention at Syafira Hospital in Pekanbaru where the work environment has a positive and 
significant effect on job satisfaction on nurses at Syafira Hospital Pekanbaru. In a study conducted by Novena (2018) also showed that the work environment simultaneously had a significant effect on employee job satisfaction. Intan Research (2017) on the Effect of Work-Life Balance and Work Environment on Employee Job Satisfaction in Nurses at Lavalette Hospital Malang showed the same results (Novena, 2018; Anderson, 2017; Intan, 2017).

A conducive work environment provides a sense of security and allows employees to work optimally. If the employee likes the work environment where he works, the employee will feel comfortable at work to carry out activities so that work time is used effectively and optimistically. The comfort of the workplace and the availability of various facilities needed to carry out the work. Comfort can be associated with adequate lighting, ventilation that provides freshness, cleanliness of the workplace, and easy to see aspects - the above aspects are a source of job satisfaction because it can facilitate the implementation of tasks is also a non-material appreciation for someone (Syafrina, 2018; Sofiyan, 2018; Dala, 2015).

The work atmosphere is a non-physical work environment. The working atmosphere can support the growth of employee morale and significantly affect the achievement of organizational goals. An excellent working atmosphere can be created with a good organization, and a clear division of tasks can create a healthy work atmosphere so that it can foster employee morale (Sofiyan, 2018).

The completeness of the tools is one of the supports in creating the right work environment. The quality of interpersonal relationships between colleagues and superiors and subordinates is high $(76 \%)$. According to Kamajaya (2013), relations between workers are part of extrinsic motivation which can cause people to participate maximally because of external stimuli. A good working relationship will be described in a close and mutual working relationship between fellow employees, and employees and leaders will have a good influence on job satisfaction and lead to improved performance (Lystiarini, 2018; Sofyan, 2018; Yuliana, 2017; Kamajaya, 2013)

\section{Effect of Organizational Factors on Job Satisfaction}

In this study, job security, excellent company policy of involvement in large organizations, high training, rewards for high achievements and career development are in the high category so that this causes job satisfaction to also be in the high category. The results of this study are consistent with research conducted by Putri (2016) on the application of the theory of constraint to the job satisfaction of employees of Undaan Surabaya Hospital where organizational factors are the organizational elements that shape the work environment and which facilitate or prevent employees from getting what is important to them from their work (Putri, 2016).

According to research conducted by Fitriani (2018), compensation which is part of organizational factors influences job satisfaction of nurses in the inpatient room of Kardinah City Hospital in Tegal, meaning that an increase in compensation will provide an increase in nurse job satisfaction in the inpatient room at Kardinah City Hospital in Tegal. Hasibuan (2007) in Fitriani
(2018) states that compensation is all income in the form of money, direct or indirect goods received by employees in return for services provided to the company, in other words, wages which are indicators in organizational variables are part of compensation (Fitriani, 2018).

The second indicator in organizational factors in this study is job security which includes health insurance and pension insurance. Research by Muda (2017) states that one of the efforts that companies can do to arouse employee morale is by providing old-age insurance or commonly called retirement. In addition to retirement insurance, health insurance directly provides a feeling of security so employees can work without feeling depressed about the conditions and circumstances, this will also relieve employees in case of illness and to carry out the treatment process (Muda, 2017).

The third indicator in organizational factors in this study is company policy, where company policy is a guideline that sets out the rules used by the company for decision making. Company policies must be flexible and easily interpreted and understood by all employees. According to Carl J Fredrick in Rifangga (2018), policies are made in order to achieve individual goals such as performance and productivity. The better company policy, the higher the performance of employees and Based on research conducted by Fitriani (2018), a person's performance is influenced by job satisfaction (Rifangga, 2018; Fitriani, 2018).

The fourth indicator of organizational factors in this study is involved in organizations, which according to Robbins (2008) in Basten (2018), involvement in organizations is defined as a measure to which individuals psychologically side with their work and consider the level of performance achieved as self-esteem. This is often demonstrated in response to work, behaviour involved in work, a sense of responsibility towards work, and feelings about work that has not been completed and absenteeism. Involvement has a positive and significant effect on job satisfaction (Basten, 2018).

The fifth indicator in organizational factors in this study is training. According to research conducted by Saprudin (2018), training has a direct and positive effect on job satisfaction. Sedarmayanti (2011) in Saprudin (2018) states that training and development are efforts to reduce or eliminate the gap between the ability of employees with the desired organization. The effort is made through increasing the work capabilities of employees by increasing knowledge and skills and changing attitudes. In addition to job satisfaction, training is also aimed at increasing work productivity, improving work quality, increasing accuracy in HR planning, improving work morale, maintaining health and safety and supporting personal growth (Saprudin, 2018; Sutrisno, 2013).

The sixth indicator in organizational factors in this study is an appreciation for achievement. According to Nursaadah's research (2016), rewards in work will affect job satisfaction which will then lead to the employee's performance. With the appreciation will arise satisfaction on the employee, which will ultimately make the employee more productive. Appreciation for achievement is very instrumental in increasing employee satisfaction, is one form of a positive assessment of employees on the achievements and work 
done by employees. So that if rewards for achievement are increased, job satisfaction will also increase (Nursaadah, 2016).

The seventh indicator in organizational factors in this study is career development. Career development is a formal approach that organizations take and use to ensure that people with appropriate skills and experience are available when needed. Benefits for workers with career planning can better understand and identify desired career goals. While the benefits for the organization are to be able to communicate career opportunities to workers and obtain a better fit between the aspirations of workers and organizational opportunities (Bagus, 2017).

\section{Effect of Individual Factors on Job Satisfaction}

In this study, individual factors do not affect job satisfaction due to the unequal distribution of respondents, where respondents are dominated by age ranges from 26 years to 35 years $(67 \%)$ while only $4 \%$ are aged between 46 years to 55 years, and all respondents have high job satisfaction. The working period is dominated by respondents with five years to 9 years $(41 \%)$, and only $10 \%$ have a $<5$ years of service. While the level of education is dominated by Diploma III of Nursing $(86 \%)$. Based on the results of the study, an increase in individual factors is not followed by an increase in the value of job satisfaction but other factors namely the work environment and organization that makes job satisfaction remain high.

The results of this study are consistent with research conducted by Kemala (2016) on Individual Characteristics, Job Characteristics and Organizational Characteristics Influence on Employee Job Satisfaction where the results of his research show that individual characteristics do not affect job satisfaction. Meanwhile, according to Mobley et al. (1978) in Nur (2016), several factors cause turnover intentions (Turnover Intention), such as age, education, marital status (Kemala, 2016; Nur, 2016).

Indicators of individual factors in this study are age, years of service and education level. Mc. Clelland in Fritz (2011) said that $90 \%$ increase in work productivity depends on workers including IQ, age, sex, education, years of service, emotions and perception. The worker factor is a significant contribution in influencing job satisfaction. Research conducted by Fritz (2011) shows that there is no relationship between age and job satisfaction. (Fritz, 2011).

In this study, factors that might cause why individual factors where the age of one indicator is not related to job satisfaction of nurses are due to the unequal age of respondents, dominated by respondents aged 36 - 45 years, in other age groups less than the age group the others thus affect the distribution of respondents.

The working period of respondents is dominated by 5-9 years and 10-14 years. People who are longer in a job will be more productive and feel satisfied with their work. Seniority is negatively related to absenteeism. Often absent and in total lost workdays, years of service are the single most important explanatory variable. Because of this study, the most extended working group is less than the other tenure groups so that the individual factor variables have no significant effect on nurse job satisfaction (Fritz, 2011).

The education level of the respondents was dominated by Diploma III of Nursing. Research conducted by Hardiana (2015) shows that education level influences the job satisfaction. In this study, individual factor variables are not related to job satisfaction, possibly due to the unequal distribution of respondents where the percentage of education level is too far between groups (Hardiana, 2015).

\section{Effect of Work Environment, Organizations and Individual} Factors on Job Satisfaction

Based on the results of this study it is known that organizational factors that most influence job satisfaction, this can be seen from the influence of wages, job security, involvement in organizations, training, rewards for achievement and career development in line with increased job satisfaction. This is reinforced by work environment factors where workplace safety, workplace atmosphere, completeness of work tools and the quality of interpersonal relationships between coworkers and superiors and subordinates that lead to job satisfaction. However, individual factors that do not influence job satisfaction are seen from the results of the study all respondents have high job satisfaction.

The work environment is one of the factors that can influence employee job satisfaction. The work environment is determined by management's attitude towards people and relationships between employees and between employees in groups and individually. A right work environment is described as a safe, comfortable, clean and quiet workplace, right equipment, good colleagues, understanding leaders who will provide employee satisfaction. Employee job satisfaction that is influenced by the work environment includes workload, work time, workplace security, relationships between work units, relations between employees, relations with superiors, completeness of work tools, and workplace atmosphere (Putri, 2016).

\section{CONCLUSION}

Based on the results of research and discussion, it can be concluded as follows:

1. Work environment factors influence the job satisfaction of nurses in the Inpatient Installation at Suaka Insan Hospital Banjarmasin

2. Organizational factors influence job satisfaction of nurses at in the Inpatient Installation at Suaka Insan Hospital Banjarmasin.

3. Individual factors did not influence the job satisfaction of nurses in the Inpatient Installation at Suaka Insan Hospital Banjarmasin.

4. Work environment, organization and individual factors jointly influence the job satisfaction of nurses in the Inpatient Installation at Suaka Insan Hospital Banjarmasin.

\section{REFERENCES}

Anderson, J., Fitri, K., \& Marhadi, M. (2017) Effects of Leadership and NonPhysical Work Environment on Nurse Job Satisfaction Through Nurse Turnover Intention at Syafira Hospital Pekanbaru. An online journal of economics students at Riau University. 4 (1).

Arini, Esqha. (2018) Relationship of Leadership, Motivation and Compensation with Job Satisfaction of Inpatient Nurses at Puri Husada Hospital Tembilahan 2017. 2017. Scientific Journal of Architects. 3 (3). http://makarioz.sciencemakarioz.org/index.php/JIM/article/view/18 
Bagus. (, 2017). Effect of Motivation, Career Development on Job Satisfaction and Nurse Performance at the Hospital dr. Soebandi Jember. Bhishma. 11 (1) https://jurnal.unej.ac.id/index.php/bisma/article/view/6207 (accessed 12 December 2019)

Basten, KJ, Sendow, GM, Tawas, HN (2018) The Influence of Work Involvement and Work Competence on Job Satisfaction and Performance of Elementary School Teachers in Malalayang District, Manado City. Emba Journal: Journal of Economics, Management, Business and Accounting Research. 6 (4)

Dala, Petrus Wolo., Rina Trisnawati, Wiyadi. (2015) Factors Affecting Nurse Satisfaction at the Tni Au Yogyakarta Hospital. UMS Journal. http://journals.ums.ac.id/index.php/dayasaing/article/ download / 3777/2446 (accessed 15 March 2019)

Fitriani, Nur., Basukiyatno. (2018) The Effect of Compensation and Organizational Culture on Performance with Nurse Job Satisfaction Mediation in the Inpatient Room of Kardinah Regional Hospital, Tegal City. Journal Tegal ups. 1 (3) http://ejournal.upstegal.ac.id/index.php/mlt/article/view/1291/982 (accessed 12 December 2019)

Fritz (2011). The Relationship between Age, Work Period and Nurse Satisfaction in Hospital Inpatient Room dr. Koesnadi Bondowoso. The Indonesian Journal of Health Science. 1 (2).

Halim, Devy., Djohan, Agustinus Johanes, Panghiyangani, Roselina., Husaini., Marlinae, Lenie. (2018) The Effect of Service Quality and Operational Benevolence on Patient Satisfaction and Their Interest in ReHospitalization. Indian Journal of Public Health Research and Development. 8 (9).

Hardiana, N. (2015) Effects of Education and Training, Work Environment and Motivation on Employee Job Satisfaction of PT Misaja Mitra Pati (Doctoral Dissertation, Muhammadiyah University, Surakarta). Surakarta

Friani, Hilda. (2019) Profile of Insan Suaka Hospital. Suaka Insan Hospital. Banjarmasin.

Intan. Nur Maslichah., Hidayat, K. (2017). The Effect of Work-Life Balance and Work Environment on Employee Job Satisfaction (Study of the Lavalette Hospital Malang Malang 2016). Journal of Business Administration. 49 (1). http://administrasibisnis.studentjournal.ub.ac.id/index.php/jab/article/v iew/1895 (accessed 12 December 2019)

Kamajaya, Adit Putra., Frianyo, A. (2018) Effects of Intrinsic Motivation and Extrinsic Motivation on Job Satisfaction. Bhishma (business and management). 6 (1) .https: //journal.unesa.ac.id/index.php/bisma/article/view/2809 (accessed 12 December 2019)

Kamal, Nasrul., Sumiyati, Ridwan Purnama. (2018) Overview of the Work Environment, Work Communication and the Work Spirit of Nurses Lung General Hospital Dr. HA Rotinsulu Bandung Journal of Business Management $\quad$ Education. $3 \quad$ (3); 3444. http://ejournal.upi.edu/index.php/JBME/article/view/14296 (accessed 15 March 2019)

Kemala, Ice. (2016) Individual Characteristics, Job Characteristics and Organizational Characteristics Influence on Employee Job Satisfaction. Benefita Journal. 1 (1); 24-31.

Law of the Republic of Indonesia No.44 of 2009. (2009) Hospital. Jakarta.

Listyarini, W., Lie, D., Efendi, E., Sisca, S. (2018) Effects of Compensation and Work Environment on Job Satisfaction in CV Sinco Jaya Abadi Pematangsiantar. Maker: management journal. 4 (1). https://maker.ac.id/index.php/maker/article/view/86 (accessed 12 December 2019)

Mahriani, Elida. (2014) The Effect of Employee Stress and Discipline on Employee Satisfaction and Performance of PT. People's Credit Bank (BPR) Mitrathama Arthabuana in Banjar Regency. Thesis. Postgraduate Masters Program in Management of the Indonesian College of Economics (STIEI). Banjarmasin.

Muda, M., Triwijayanti, R., Romiko, R. (2017) Relationship between Nurse Job Satisfaction with Organizational Commitment in the Inpatient Room. National Seminar on Nursing. 1 http://www.conference.unsri.ac.id/index.php/snk/article/view/746 (accessed 12 December 2019)
Nur, Halimah., Fathoni, A., Minarsih, M. (2016) The Influence of Job Insecurity, Job Satisfaction and the Work Environment on the Turnover Intention of Salesperson in Gelael Supermarket (Case Study on Gelael Superindo, Semarang City). Journal of Management. 2 (2). http://jurnal.unpand.ac.id/index.php/ms/article/view/606 (accessed 12 th

Nursaadah, N. (2017) The Effect of Reward and Punishment on Job Satisfaction and Its Implications on the Performance of Spending Treasurer in Banjar City Government. Journal of Management Review. 1 (1).

Putri, Selviana Larasati., Setya Haksama. (2016) Application of Theory Of Constraint To Employee Satisfaction at Undaan Eye Hospital Surabaya, Journal of Indonesian Health Administration. 2 (4). https://ejournal.unair.ac.id/JAKI/article/view/3183/2326 (accessed March 16, 2019)

Rachman, Lutfi., Aro Dewanto. (2016) The Effect of Employee Engagement on Nurse Satisfaction and Turnover Intention (Study at Wava Husada Hospital Kepanjen Malang). Journal of Management Applications (JAM). 2 (14). https://jurnaljam.ub.ac.id/index.php/jam/article/view/893 (accessed 15 March 2019)

Renea, Ryan., Sari Wahyunib. (2018) The Effect of Work-Life Balance on Organizational Commitment, Job Satisfaction, and Work Motivation on Individual Performance in Employees of Insurance Companies in Jakarta. Sriwijaya Business and Management Journal. 16 (1) http://ejournal.unsri.ac.id/index.php/jmbs (accessed 26 March 2019)

Rifangga, R. (2018). Analysis of the Effect of Incentives, Company Policy and Work Environment on Employee Performance at PT. Prima Data Semesta Semarang. Journal of Management Accounting Economics. 25 (44).

Saprudin, S. (2018) The Effect of Training and Compensation on Employee Job Satisfaction. Journal of Information Systems, Applied, Management, Accounting and Research. 2 (1). http://journal.stmikjayakarta.ac.id/index.php/jisamar/article/view/23

Sarwono, J., Umi Narimawati. (2015) Thesis, Thesis and Dissertation with Partial LeastsquareSEM (PLS-SEM). Publisher CV Andi. Yogyakarta.

Sitepu, Alexander. (2014) Effects of Leadership Style, Job Satisfaction, Work Discipline and Training on Employee Performance (Study at Ratu Zalecha Hospital Martapura, South Kalimantan). Thesis. Postgraduate Masters Program in Management of the Indonesian College of Economics (STIEI). Banjarmasin

Sofiyan, Rizali. (2018) Effect of Work Environment and Job Satisfaction on Service Quality. Journal of management. 1 (2). http://jurnal.unigal.ac.id/index.php/managementreview (accessed 15 March 2019)

Sutrisno, E. (2013) Human Resources. Gramedia. Surabaya.

Syafrina, N. (2018) Factors That Affect Employee Job Satisfaction at PT. Aspacindo Kedaton Motor Kandis Siak Regency. Benefita Journal: Development Economics, Business Management and Accounting. 3 (3).

Yuliana, B. (2017). The Effect of Leadership Orientation and Organizational Culture on Employee Performance is mediated by Employee Job Satisfaction (Study at the Papua Province Regional Development Planning Agency). Doctoral Dissertation, Brawijaya University. Poor.

\section{AUTHORS}

First Author - Sri Rahayu, Master of Public Health, Faculty of Medicine, Lambung Mangkurat University, Indonesia.

Second Author - Roselina Panghiyangani, Department of Biomedicine, Faculty of Medicine, Lambung Mangkurat University, Indonesia.

Third Author - Lenie Marlinae, Public Health Study Program, Faculty of Medicine, Lambung Mangkurat University, Indonesia. Fourth Author - Husaini, Master of Public Health, Faculty of Medicine, Lambung Mangkurat University, Indonesia.

Fifth Author - Eko Suhartono, Department of Biochemistry, Faculty of Medicine, Lambung Mangkurat University, Indonesia. Correspondence Author - Sri Rahayu, Master of Public Health, Faculty of Medicine, Lambung Mangkurat University, Indonesia, email: sri.rahayu@bpjs-kesehatan.go.id 